\title{
The Lawsuit against the United States for Causing COVID-19
}

\section{Patthara Limsira*}

The coronavirus disease 2019 (COVID-19) presents varieties of questions concerning not only international law, but also the domestic laws of states affected by this global pandemic. One of legal issues amid COVID-19 pandemic is the state immunity principle. There have been many lawsuits against foreign state challenging the state immunity principle amid the COVID-19 pandemic. In Thailand, the Chiangmai Provincial Court (court) addressed in its judgment that it did not have jurisdiction to adjudicate the compensation for COVID-19 pandemic's damages dispute between Thai restaurant owner and the United States (US). Notwithstanding surrounding controversies over COVID-19 pandemic, the court considered the motion denied. The main implication of the judgment is that Thailand accepted state immunity principle under customary international law. This research briefly explains the sovereign immunity doctrine relating to this case, summarizes the facts and analyses the potential ramifications of this judgement under international law.

\section{Keywords}

Sovereign Immunity Doctrine, State Immunity Principle, Thailand, United States, COVID-19, Lawsuit, Application of Customary International Law

* Assistant Professor at Faculty of Law, Ramkhamhaeng University, Thailand. LL.B.(Magna Cum Laude)/LL.M. (Chulalongkorn). ORCID: https://orcid.org/0000-0002-2282-4153. The author may be contacted at: Patthara@ru.ac.th / Address: Faculty of Law, Ramkhamhaeng University, Bang Kapi, Huamark, Bangkok 10240 Thailand. I am grateful to Professor Frederick Ceely and anonymous reviewers for their careful reading of my manuscript and their many insightful comments and suggestions on the drafted versions of this article. The research assistance of Panwara Permpoon is also gratefully acknowledged. The views and opinions expressed in this article are those of the authors and do not necessarily reflect the official positions or policies of their affiliated institutions. The author also pays tribute to the healthcare workers around the world who have lost their lives in the battle against COVID-19, and expresses his sympathy for the millions of victims of the virus.

All the website cited in this article were last visited on October 14, 2020. 
Every kind of peaceful cooperation among men is primarily based on mutual trust and only secondarily on institutions such as courts of justice and police.

Albert Einstein ${ }^{1}$

\section{Introduction}

There have been many frivolous lawsuits against the People's Republic of China (China) over coronavirus disease 2019 (COVID-19). ${ }^{2}$ Most of the lawsuits were filed in the United States (US) ${ }^{3}$ and other jurisdictions around the world. ${ }^{4}$ These lawsuits commonly seek damages from China based on its role in unleashing the COVID-19 pandemic. ${ }^{5}$ These attempts seem to be contrary to international law, because they seek to bring China to a national or international judicial forum without its consent. ${ }^{6}$ Therefore, the venture will not be an easy task, but rather a herculean one. ${ }^{7}$

1 A. Einstein, Arms Can Bring No Security, 6 Bull. Atom. Scientists 71 (1950).

2 For the scientific fact concerning the COVID-19 pandemic, see M. Boni et al., Evolutionary origins of the SARS-CoV-2 sarbecovirus lineage responsible for the COVID-19 pandemic, NAtURE Microbiology (2020), https:/doi.org/10.1038/ s41564-020-0771-4; Y. Guo et al. The Origin, Transmission and Clinical Therapies on Coronavirus Disease 2019 (COVID-19) Outbreak-An update on the status, 7 Mז. Med. Res. (2020), https://doi.org/10.1186/s40779-020-002400; M. A. Shereen et al., COVID-19 infection: Origin, transmission, and characteristics of human coronaviruses, $24 \mathrm{~J}$. AdVAnCED Res. 91 (2020).

3 The jurisdictional basis has generally been the Foreign Sovereign Immunities Act (FSIA) 1976. See S. Mirski \& S. Anderson, What's in the Many Coronavirus-Related Lawsuits Against China?, (June 24, 2020), https://www.lawfareblog. com/whats-many-coronavirus-related-lawsuits-against-china; P. J. Larkin, Jr., Suing China over COVID-19, 100 B.U. L. Rev. Online (June 7, 2020), https://ssrn.com/abstract=3623369; C. Keitner, To Litigate a Pandemic: Cases in the United States against China and the Chinese Communist Party and Foreign Sovereign Immunities, 19 CHINESE J. INT'L L. 229 (2020).

4 E.g. Nigeria, see ANKARA, Nigerians sue China for \$200B over coronavirus pandemic, (July 7, 2020), https://www. aa.com.tr/en/africa/nigerians-sue-china-for-200b-over-coronavirus-pandemic/1902797; Italy, see O. Bowcott \& A. Giuffrida, From an Italian hotel to a US state, coronavirus 'lawfare' takes off, GUARDIAN, Apr. 23, 2020, https://www. theguardian.com/world/2020/apr/23/from-italian-hotel-to-us-state-coronavirus-lawfare-takes-hold.

5 Those attempts were based on the Principle of Transboundary Harm from the Trail Smelter Arbitration. See R. Miller, Hearing on the Foreign Sovereign Immunities Act, Coronavirus, and Addressing China's Culpability, U.S. Senate Committee on the Judiciary, Written Statement of Prof. Russell A. Miller, (June 23, 2020), https://www.judiciary.senate. gov/imo/media/doc/Miller\%20Testimony1.pdf. See also Transboundary Harm In InTERnATIONAL Law: LesSONS From the Trail Smelter Arbitration (R. Bratspies \& R. Miller eds., 2006). Cf. Hearing on the Foreign Sovereign Immunities Act, Coronavirus, and Addressing China's Culpability, U.S. Senate Committee on the Judiciary, Testimony of Chimène Keitner (June 23, 2020), https:/www.judiciary.senate.gov/imo/media/doc/Keitner\%20Testimony.pdf.

6 M. Shaw, International Law 559-61 (8th ed. 2017).

7 E. Trigt, Could China be Taken to ICJ over COVID-19 Pandemic? (May 12, 2020), https://www.peacepalacelibrary. nl/2020/05/could-china-be-taken-to-icj-over-COVID-19-pandemic. 
There is a lack of solid evidence ${ }^{8}$ for the conspiracy that either the deadly virus is a Chinese bioweapon or the lab released a natural virus. ${ }^{9}$ However, the Chinese government did appear to have tried to cover up the outbreak when it began spreading globally. ${ }^{10}$ Also in Thailand, litigation concerning state responsibility on COVID-19 has been filed. The defendant in this particular case was not China, but the US. On June 26, 2020, a restaurant owner in Thailand filed a claim alleging that the US ignored the evidence and suing it for causing the COVID-19 pandemic. ${ }^{11}$ The intention of the restaurant owner to proceed in propria persona was that his litigation could serve as a guideline for other Thai business owners in the foreign countries to step up and claim their rights. ${ }^{12}$ With the line in the sand having been drawn, the Thai court delivered its decision.

The primary purpose of this research is to look into the legal issues of the Thai restaurant owner's lawsuit against the US. This paper is composed of five parts including Introduction and Conclusion. Part two will briefly explain the background and substance of the sovereign immunity doctrine in line with this case. Part three will summarize the judgment and review the proceedings before the court. Part four will make some commentary on the ramifications of the judgment and analyze its main points under international law.

8 S. Liu et al., No credible evidence supporting claims of the laboratory engineering of SARS-CoV-2, 9 EMERGING Microbes \& InFECTIONS 505 (2020); M. Beusekom, Scientists: 'Exactly zero' evidence COVID-19 came from a lab, CIDRAP NEws, May 12, 2020, https://www.cidrap.umn.edu/news-perspective/2020/05/scientists-exactly-zeroevidence-COVID-19-came-lab; Z. Yusha, WHO admits Wuhan may not be virus origin, offsetting rumor, GLOBAL TimeS, Aug. 4, 2020, https://www.globaltimes.cn/content/1196713.shtml.

9 J. Rogin, State Department cables warned of safety issues at Wuhan lab studying bat coronaviruses, WASH. Post, Apr. 14, 2020, https://www.washingtonpost.com/opinions/2020/04/14/state-department-cables-warned-safety-issues-wuhanlab-studying-bat-coronaviruses; B. Baier \& G. Re, Sources believe coronavirus outbreak originated in Wuhan lab as part of China's efforts to compete with US, Fox NEws, Apr. 15, 2020, https://www.foxnews.com/politics/coronaviruswuhan-lab-china-compete-us-sources.

10 F. Chen, COVID-19 may be man-made, claims Taiwan scholar, AsIA TIMES, Feb 24, 2020, https://asiatimes.com/ 2020/02/COVID-19-may-be-man-made-claims-taiwan-scholar.

11 Thai Cafe Owner Sues US Govt for Spreading COVID-19, Seeks \$14,500 in Damage Compensation, YAHoo News, July 1, 2020, https://in.news.yahoo.com/thai-cafe-owner-sues-us-114600746.html.

12 The Famous Lawyer and Restaurant Owner is suing US for Spreading COVID and Seeking in Damage Compensation (June 26, 2020), https://www.posttoday.com/social/local/627024<available only in Thai >; The Restaurant Owner sue America for Spreading COVID in Chiangmai Provision Court for the 450,000 lost (June 27, 2020), https://www. banmuang.co.th/news/region/197254<available only in Thai>; Chiangmai Restaurant Owner sue America for causing COVID-19 global outbreak and damage, (June 27, 2020), https://www.komchadluek.net/news/regional/435310. $<$ available only in Thai > 


\section{The Sovereign Immunity Doctrine: Today's Context $^{13}$}

It is a basic principle ${ }^{14}$ of international law that states are immune from the jurisdiction of foreign municipal courts. ${ }^{15}$ This is based on reciprocity and comity. ${ }^{16}$ Foreign states may rely on sovereign immunity with respect to conduct in the exercise of sovereign authority (iure imperii) ${ }^{17}$ and their dignity as independent states. ${ }^{18}$ Later developments covered certain groups of individuals and institutions, ${ }^{19}$ inter alia, foreign heads of state, diplomatic agents, and international institutions and their officials and agents. The foreign sovereign immunity was rooted in the immunity of the person of the monarch. ${ }^{20}$ That seemed natural when kings were considered to be the embodiment of a state's sovereignty and when diplomatic agents were considered to be personal representatives of the monarchy. One sovereign monarch could not be subject to the jurisdiction of another sovereign monarch since all kings were equal and the king can do no wrong. ${ }^{21}$ These echoes from par in parem non habet imperium (equals have no sovereignty over each other), one of the Latin maxims in international law. ${ }^{22}$ A king would not be subject to the jurisdiction of another state while visiting the state, and by extension a monarchy's representatives were also granted immunity. ${ }^{23}$ Today,

13 See generally H. Fox \& P. Webb, The Law of State Immunity (3d ed. 2015); X. Yang, State Immunity in InTERNATIONAL LAW (2012).

14 Some scholar suggested that the jurisdictional immunity should be a rule instead of a principle of international law. See J. Finke, Sovereign Immunity: Rule, Comity, or Something Else? 21 Eur. J. INT’L L. 853 \& 857, (2010).

15 Special Rapporteur, Preliminary Report on Jurisdictional Immunities of States and Their Property, ๆ 22, U.N. Doc. A/ CN.4/323, reprinted in 2 Y.B. INT'L L. CoMm'N 231 (1979).

16 H. Fox, International Law Restraint on the Exercise of Jurisdiction, in INTERNATIONAL LAW 388 (M. Evans ed., 2d ed., 2014).

17 J. Crawford, Sovereignty as a Legal Value, in The Cambridge Companion to International Law 117-133, 125 (J. Crawford \& M. Koskenniemi eds., 2012).

18 The Parlement Belge, LR 5 P.D. 197, at 214-15 (1880).

19 A. Cassese, International Law 110-23 (2d ed. 2005); Shaw, supra note 6, at 554-9.

20 R v Bow Street metropolitan stipendiary Magistrate and others, exparte Pinochet Ugarte (Amnesty International and other intervening) (No.3), 2 All E.R. 97, House of Lords (1999).

21 F. Pollock \& F. Maitland, The History of English Law Before the Time of Edward I, 515-8 (2d. ed. 1899); R. Watkins, The State as a Party Litigant 1-13 \& 192-207 (1927); E. Borchard, Governmental Responsibility in Tort, 36 YaLe L. J. 1 (1926).

22 L. Caplan, State Immunity, Human Rights, and Jus Cogens: A Critique of the Normative Hierarchy Theory, 97 Am. J. INT'L. L. 748 (2003). See also S. Knuchel, State Immunity and the Promise of Jus Cogens, 9 Nw. U. J. Int’L Hum. Rts. 149 (2011); Jones v. Ministry of Interior of the Kingdom of Saudi Arabia, [2006] UKHL 26 (H.L. June 14, 2006); Al-Adsani v. The United Kingdom, ECtHR 21 November 2001, ๆ 56; Lambège et Pujol, French Cour de cassation, Sirey 1849, I, 81.

23 Since the Treaty of Westphalia, the principle of state immunity has been largely uncontroversial. See W. Nagan \& A. Haddad, Sovereignty in Theory and Practice, 13 SAN Diego InT'L L. J. 429 (2012). 
however, the linkage between state and monarch began to fade away, leaving only states to maintain absolute immunity and extend it to other states. ${ }^{24}$

A State relies on the classical concept of state immunity either to claim that a particular court does not have jurisdiction over it, or to prevent enforcement of a judgement against any of its assets, ${ }^{25}$ which would include state owned entities. ${ }^{26}$ Another essential aspect of state immunity is based on the equality of sovereignty, ${ }^{27}$ independence, and dignity, ${ }^{28}$ which are the bases of non-intervention in the internal affairs of other states. ${ }^{29}$ Court proceedings against foreign states definitely generate tensions and interfere with the conduct of international relations. Any attempt to pass on the question would embarrass the executive seeking to arrive at an appropriate diplomatic settlement. ${ }^{30}$

However, immunity from jurisdiction does not mean exception from the legal system of the territorial state in question. ${ }^{31}$ As a result, no principles of international law are more fundamental or more universally accepted than the state immunity principle. ${ }^{32}$ There used to be only the doctrine of absolute immunity from the jurisdiction of domestic courts unless a waiver of immunity could be obtained. ${ }^{33}$ The jurisdictional immunities of states are derived mainly from the numerous judicial branch practices, ${ }^{34}$ which have been incorporated into the legal systems of the majority of modern states. ${ }^{35}$

As time passed, the principle of state immunity evolved from a doctrine of absolute immunity to a doctrine of restrictive immunity, ${ }^{36}$ in which a foreign state would be accorded immunity only for claims arising out of sovereign or public acts

24 J. Dunoff, International law-Norms, Actors, Process: A problem oriented approach 383 (2002).

25 G. Pugh, Historical Approach to the Doctrine of Sovereign Immunity, 13 LA. L. REv. 476-94 (1953).

26 R. Garcia, Sovereign Immunity: Whose assets are they freezing anyway?, 29 Butterworths J. Int'L Banking \& Fin. L. 50-2 (2014).

27 J. Bodin, Six Books of the Commonwealth 43 (trans by M. Tooley, 1955).

28 P. Oguno, The Concept of State Immunity under International Law: An Overview, 2 InT'L J. L. 12 (2016).

29 I. Brownlie, Principles of Public International Law 326 (7th ed. 2008).

30 Banco Nacional de Cuba v. Sabbatino, 376 U.S. 398 (1964). For details, see S. Malawer, The Act of State Doctrine and the City Bank Case: A Proper Role for the Judiciary in the World Public Order, 1 U. Balt. L. Rev. 70 (1971); F. Dawson \& B. Weston, Banco Nacional de Cuba v. Sabbatino: New Wine in Old Bottles, 31 U. ChI. L. Rev. 63 (1963).

31 Shaw, supra note 6 , at 525.

32 Y. Dinstein, Par in Parem non Habet Imperium, 1 IsRael L. Rev. 407 (1966).

33 H. Fox, The Law of State Immunity 262-71 (2002).

34 S. Sucharitkul, State Immunities and Trading Activities in International Law 3 (1959). See also the United States Supreme Court judgement of The Schooner Exchange v. McFaddon and Others, 11 U.S. 116 (1812).

35 J. Hervey, The Immunity of Foreign States When Engaged in Commercial Enterprises: A Proposed Solution, 27 MicH. L. Rev. 751 (1929).

36 Victory Transport, Inc. v. Comisaria General (1965) 336 F.2d 354, 381 U.S. 934; Saudi Arabia v. Nelson, 507 U.S. 349, 361 (1993). 
(acta jure imperii), as opposed to claims arising out of its commercial transactions or private legal activities (acta jure gestionis). ${ }^{37}$ Sovereign Immunity remain an important underlying factor in much transnational litigation. ${ }^{38}$ However, the details of state immunity are not always certain. ${ }^{39}$ They are frequently abstract and mysterious, since there is persistent divergence between adherents of the doctrine of absolute immunity and those who back restrictive immunity. ${ }^{40}$

Regarding the rules on state immunity, a crystallization of customary international law was achieved at the Council of Europe in 1972, which promulgated the European Convention on State Immunity ${ }^{41}$ with its additional protocols to establish the European Tribunal in matters of State Immunity. ${ }^{42}$ Those instruments were the first comprehensive multilateral treaties to be concluded on the matter.

In 1977, the United Nations General Assembly adopted Resolution 32/151 on the state immunity in the work program of the International Law Commission (ILC). ${ }^{43}$ The goal was to standardize the state practices, because the diversity and consequent uncertainty in law was causing confusion. ${ }^{44}$ The resulting journey lasted almost 27 years. The ILC was forced to work through the deep divisions among state representatives in the General Assembly's Sixth (Legal) Committee and ad hoc committees $^{45}$ to culminate in a finalized version of the Draft Articles on Jurisdictional Immunities of States and their Property 1991, accompanied by a set of annexed understandings. Finally, the United Nations Convention on Jurisdictional Immunities of States and Their Property (UNCSI) was adopted by the General Assembly in $2004 .^{46}$ The UNCSI maintains a restrictive approach, ${ }^{47}$ but the degree to which the restrictive

37 T. Hill, A Policy Analysis of the American Law of Foreign State Immunity, 50 FordHam L. Rev. 155, 162-3 (1981).

38 J. Dunoff, International law - Norms, Actors, process: A problem Oriented Approach 384 (2002).

39 J. Dellapenna, Foreign State Immunity in Europe, 5 N.Y. InT'L L. Rev. 61 (1992).

40 C. Schreuer, State Immunity: Some Recent Developments 168 (1988).

41 It was come into force in 1976. There are only eight state parties: Austria, Belgium, Cyprus, Germany, Luxembourg, the Netherlands, Switzerland and the United Kingdom.

42 Additional Protocol to the European Convention on State Immunity came into force in 1985. There are six state parties: Austria, Belgium, Cyprus, Luxembourg, The Netherlands and Switzerland.

43 Noting that Sompong Sucharitkul from Thailand was appointed as a chairman of the working group to consider the question of future work by the Commission on the topic "Jurisdictional immunities of States and their property" and an ILC's Special Rapporteur for the topic in 1977. See [1978] 2 Y.B. Int'1 L. Comm'n: Part Two report of the commission to the General Assembly on the work of its thirtieth session 152-3 (1978).

44 E. Bankas, The State Immunity Controversy in International Law: Private suits against sovereign states in DOMESTIC COURTS 202-7 (2005).

45 G. Hafner, Historical Background to the Convention, in The United Nations Convention on Jurisdictional Immunities of States and Their Property: A commentary 1-12 (R. O’Keefe et al. eds., 2013).

46 G.A. Res. 59/38 (Dec. 2, 2004) (adopted without a vote).

47 A. Aaken, Blurring Boundaries between Sovereign Acts and Commercial Activities: A functional view on regulatory 
approach is recognized by states is still a point of contention. ${ }^{48}$

The UNCSI shall enter into force after it has been signed and ratified by 30 states. ${ }^{49}$ At present, the Convention has been signed by 28 states and ratified by 22 states. ${ }^{50}$ Considering the development of the sovereign immunity principle through the years, the UNCSI is a great achievement in the sense that states have agreed on a multilateral treaty which does not allow states to have absolute immunity in the foreign courts. Therefore, if any state did not have domestic laws on state immunity, the provisions in the UNCSI would be available as a model for the new legislation. But for states with their own laws, the UNCSI would improve the legal position of people or companies hoping to start proceedings in other states, allowing them to be confident that litigation will follow the same basic approach across the world. ${ }^{51}$

Last but not least, during the previous decade, there were a number of events that had affected the changing nature of sovereign immunity combined with jus cogens. ${ }^{52}$ These had impacted the dynamic of contemporary international law. The emergence of jus cogens principles clearly placed them in a higher rank than other international law principles ${ }^{53}$ in the normative hierarchy, which included state sovereignty and sovereign immunity as well. Furthermore, there was a very important development from the Italian court, ${ }^{54}$ which asserted jurisdiction concerning human rights violations during the Second World War by Germany in civil cases. ${ }^{55}$ In return, Germany brought

immunity and immunity from execution, in Immunities IN the Age of Global Constitutionalism 131-86 (A. Peters et. al. eds., 2014).

48 W. Shan \& P. Wang, Divergent Views on State Immunity in the International Community, in The CAmBridge HandBook of Immunities and International Law 61-78 (T. Ruys, N. Angelet \& L. Ferro eds., 2019); R. Higgins, Problems and Process: International LaW and How We Use 80 (1994).

49 UNCSI art. 30.

50 The United Nations Convention on Jurisdictional Immunities of States and Their Property, (Oct. 8, 2020), https:// treaties.un.org/doc/Publication/MTDSG/Volume\%20I/Chapter\%20III/III-13.en.pdf.

51 UNCSI pmbl.

52 Vienna Convention on the Law of Treaties, art. 53. See T. Weatherall, The formal source of peremptory norms, in Jus Cogens: International Law and Social Contract 124-74 (2015); J. Menkes, Article 53 of the Vienna Convention on the Law of Treaties -Codification or Development?, 2 Polish Rev. InT'L \& Eur. L. 9 (2013); M. Villiger, Article 53: Treaties Conflicting with A Peremptory Norm of General International Law (Jus Cogens), in Commentary on the 1969 Vienna Convention on the Law of Treaties 661-78 (2009); K Schmalenbach, Article 53, in Vienna Convention on the LAW of Treaties: A commentary 965-1012 (O. Dörr \& K. Schmalenbach eds., 2018).

53 T. Kleinlein, Jus Cogens Re-examined: Value formalism in international law, 28 Eur. J. InT'L L. 295 (2017); K. Robert, Peremptory International Law - Jus Cogens: A general inventory (2015); W. Thomas, Jus Cogens: International Law and Social Contract (2015); D. Shelton, Normative Hierarchy in International Law, 100 Am. J. Int’l L. 291 (2006); A. Orakhelashvili, Peremptory Norms in International Law (2006).

54 Supreme Court of Cassation (Corte Suprema di Cassazione) is the highest court of appeal or court of last resort in the Italian judicial system. See J. Merryman \& V. Vigoriti, When Courts Collide: Constitution and Cassation in Italy, 15 Ам. J. Cомp. L. 665 (1966-67).

55 See, e.g., Ferrini v. Republica Federale di Germania, Corte di Cassazione, Joint Sections, Judgment 6 November 
the dispute to the International Court of Justice (ICJ) in 2008. The ICJ released its judgment in 2012, ruling that Italy violated international law in asserting jurisdiction over Germany for jus cogens abuses and there was no such exception recognized in customary international law anymore. ${ }^{56}$ The decision was not unanimous, however. As it was vehemently contested, strong dissents were also delivered. ${ }^{57}$ When a norm attains the character of jus cogens, an obligation of erga omnes ${ }^{58}$ is imposed upon the community of states as a whole. ${ }^{59}$

At present, the current position of sovereign immunity is still considered under international law to be an ongoing issue in light of the rising importance of jus cogens. ${ }^{60}$ The state practice and case law have been and will be significant pillars in the international law system. This will allow further developments of the law in line with the needs of governments, international organization and other entities. Although the UNCSI demonstrated some success in the conclusion of a multilateral treaty on this issue, the treaty remains unratified yet. As such, it has not taken force.

\section{Judgement of Civil Case Black No. Po. 1062/2563: A Summary ${ }^{61}$}

The lawsuit was filed on June 26, 2020. The plaintiff, Mr. Savet Vienthong, was an

2003-11 March 2004, n. 5044 (“Ferrini Case"). Ferrini Judgment No. 5044/2044, 11 March 2004, Rivista di diritto internazionale 87 (2004), 539. For English translation, see 128 I.L.R. 659.

56 Jurisdictional Immunities of the State (F.R.G. v. Italy: Greece intervening), Judgment, 2012 I.C.J. Rep. 99 (Feb. 3). See also A. Orakhelashvili, Jurisdictional Immunities of the State, 106 Am. J. InT'L L. 609-16 (2012); P. Gragl, Jurisdictional Immunities of the State in International Law, in THE OXFORD HANDBOOK OF JURISDICTION IN INTERNATIONAL LAW 228-50 (S. Allen et al. eds., 2019); R. Higgins, Equality of States and Immunity from Suit: A complex relationship, in Neth. Y.B. INT'L L. 129-49 (2012) (J. Nijman \& W. Nijman eds., 2013).

57 Jurisdictional Immunities of the State (Germany v. Italy: Greece intervening), Judgment, 2012 I.C.J. Rep. 179-290 (Dissenting opinions of Judge Cançado Trindade); Dissenting opinions of Judge Yusuf, $i d$. at 291-308; Dissenting opinions of Judge Ad Hoc Gaja, id. at 309-22.

58 Barcelona Traction, Light and Power Company, Limited (Belg. v. Spain), Judgment, 1970 I.C.J. Rep. 3. ๆ 33 (Feb. 5); Application of the Convention on the Prevention and Punishment of the Crime of Genocide (Bosn. \& Herz. v. Serb. \& Montenegro), Judgment, 2007 I.C.J. Rep. 43, 110 (July 11).

59 Brownlie, supra note 29, at 597. See also Prosecutor v. Furundzija, Case No. IT-95-17/1-T, at 1 ๆ 260-262.

60 W. Nagan \& J. Root, The Emerging Restrictions on Sovereign Immunity: Peremptory Norms of International Law, the U.N. Charter, and the Application of Modern Communications Theory, 38 N.C. J. INT'L L. \& Com. Reg. 375-471 (2013).

61 An unreported judgment. See Chiangmai Provincial Court delivers the Judgment of Thai Citizen sue America for Spreading Covid, THAi Post, July 8, 2020, https://www.thaipost.net/main/detail/70863 <available only in Thai>; Chiangmai Provincial Court dismiss Au's café law sued America asking for 450000 (baht) compensation in damage for Spreading Covid, Matichon OnLine, July 8, 2020, https://www.matichon.co.th/local/crime/news_2259014. <available only in Thai> 
attorney who acts the manager of Au's café, together with Mr. Pattarasak Vientong, his grandson and business partner in the café. The defendant is the US, a juristic person under international law. According to the plaintiff, the tortious actions of defendant injured numerous individuals in many countries, including Thailand. Although the defendant did not have a domicile in Thailand, the plaintiff has one in Chiang Rai province. In accordance with section 4 ter of the Civil Procedure Code, ${ }^{62}$ the plaintiff submitted the complaint to the Civil Court in the domicile of the plaintiff, choosing to file the complaint at Chiangmai Provisional Court in the end of year 2019, after the spread of the pandemic of COVID-19 all around the world, including Thailand. The plaintiff was encouraged on May 26, 2020, when he received on social media news that the Coronavirus had originated in humans whose source was allegedly Virus Lab BSL-3 Biocontainment Facility in North Carolina, the US.

Plaintiff argued that he received information from the tweets of Greg Rubini's Twitter account and an American television channel in which he said that the COVID-19was designed as a biological weapon in the BSL-3 Biocontainment Facility in North Carolina. It had been developed there by Professor Ralph Baric. ${ }^{63}$ Mr. Rubini also said that the virus was delivered by the Dark Government in North Carolina to China, Italy, and other countries. ${ }^{64}$ Professor Luc Montagnier, a Nobel laureate who discovered the Human Immunodeficiency Virus (HIV) 2008, told a French reporter that COVID-19 had not arisen from nature, but rather had been intentionally developed by molecular biologists and other experts. Other news media rumors suggested that the virus had been taken from bats and subjected to intensive HIV

62 Section 4 ter of Thailand Civil Procedure Code provides:

"The other plaint as provided other than the Section 4 bis which the defendant is not domiciled within the Kingdom and the cause is not arose within the Kingdom, if the plaintiff has Thai nation or domicile within the Kingdom. It shall be submitted to the Civil Court or to the Court within the territorial jurisdiction of which the Plaintiff is domiciled. In the case of the plaint according to the first paragraph, if the defendant has the property liable to execution within the Kingdom, irrespective of temporization or permanence, the plaintiff shall submit the plaint to the Court within the terrestrial jurisdiction of which such property is situated."

Section 4 bis of Thailand Civil Procedure Code provides:

"The plaint concerning immovable property, or any right or interest concerning immovable property shall be submitted to the court within the territorial jurisdiction of which the immovable property is situated, whether the defendant shall have domicile within the Kingdom or not, or to the Court within the territorial jurisdiction of which the defendant is domiciled."

63 See Coronavirus was created in an American Lab in 2015, People's MAG., Apr. 10, 2020, https://peoplesmagazine. in/2020/04/10/coronavirus-was-created-in-an-american-lab-in-2015.

64 J. Whitehouse, Pro-Trump OAN pushes wild conspiracy theory that novel coronavirus was created in a North Carolina lab, Media Matters for America (Mar. 18, 2020), https://www.mediamatters.org/coronavirus-covid-19/pro-trump-oanpushes-wild-conspiracy-theory-novel-coronavirus-was-created. Cf. Z. Eanes, Debunked COVID-19 conspiracy theory weaves a UNC medical researcher into the tale, NEWS OBSERVER, Apr. 16, 2020, https://www.newsobserver.com/news/ local/article241996426.html. 
genetic modification. $^{65}$

Plaintiff's documents on file claim this to be the cause of the COVID-19 pandemic. Plaintiff seeks access to important data from many sources, and will deliver the information to the court before examining the evidence as the plaintiff asked earlier. It is claimed that in this manner, defendant injured plaintiff by causing COVID-19 to spread into Thailand, urging the Thai government to issue the Declaration of an Emergency Situation pursuant to the Emergency Decree on Public Administration in Emergency Situations B.E. 2548 (2005), ${ }^{66}$ thereby closing all restaurants and other businesses. $^{67}$

Plaintiff has been doing the restaurant business since 2019, focusing on serving drinks in air con and open-air spaces. Plaintiff claims a benefit after costs of 5,000 baht (approximately USD 160) a day/150,000 baht a month (approximately USD 4,777). The 'close' regulation caused by the COVID-19, presumably caused by the action of the defendant, covered the period from March 26 to June 30, 2020, inflicting a monetary loss on plaintiff in the amount of 450,000 baht (approximately USD 14,572). Plaintiff also prays for 7.5 per cent interest per annum to compensate for their lack of income during the lockdown. ${ }^{6}$

However, on July 8, 2020, Chiangmai Provincial Court, holding that the defendant is a foreign state, having sovereign immunity rights under customary international law, found that it did not have jurisdiction over this case and considered the motion denied. $^{69}$

65 See French Nobel prize winner: 'Covid-19 made in lab,' Connexion, Apr. 22, 2020, https://www.connexionfrance. com/French-news/Disputed-French-Nobel-winner-Luc-Montagnier-says-Covid-19-was-made-in-a-lab-laboratory. $C f$. Spotlight: COVID-19 virus not created in lab, say French experts, XINHUANET, Apr. 21, 2020, http://www.xinhuanet. com/english/2020-04/21/c_138995413.htm; P. Lacoude, No, SARS-CoV-2 does not contain HIV genetic code! (Apr. 18, 2020), https://www.europeanscientist.com/en/big-data/no-sars-cov-2-does-not-contain-hiv-genetic-code.

66 Official Statement of the Office of the Prime Minister, Declaration of an Emergency Situation pursuant to the Emergency Decree on Public Administration in Emergency Situations B.E. 2548, (Mar. 25, 2020), https://image.mfa. go.th/mfa/0/mkKfL2iULZ/migrate_directory/news3-20200326-211539-804409.pdf.

67 Regulation Issued under Section 9 of the Emergency Decree on Public Administration in Emergency Situations B.E. 2548 (2005) (No. 1), (Mar. 25, 2020), https://image.mfa.go.th/mfa/0/mkKfL2iULZ/migrate_directory/news320200329-164122-910029.pdf.

68 T. Nguyen, Thailand: A cafeteria files lawsuit against US government for allegedly spreading Covid-19, VIETNAM TIMES, July 2, 2020, https://vietnamtimes.org.vn/thailand-a-cafeteria-files-lawsuit-against-us-government-for-allegedlyspreading-covid-19-21884.html; Thai cafe files lawsuit against US govt for allegedly spreading Covid-19, STAR, July 1, 2020, https:/www.thestar.com.my/aseanplus/aseanplus-news/2020/07/01/thai-cafe-files-lawsuit-against-us-govt-forallegedly-spreading-covid-19.

69 Supra note 61. 


\section{Commentaries}

There are two main legal points at issue under international law from ramifications of the judgment. One is Thailand's recognition of customary international law, and the other is the principle of state immunity.

\section{A. Thailand's Application of Customary International Law}

The international and domestic legal system interact frequently, despite being separate entities. The state cannot rely on their domestic law to avoid international law obligations, ${ }^{70}$ which rely on pacta sunt servanda principles. ${ }^{71}$ Those obligations bind the state through various sources of international law, both traditional and material sources beyond the scope of Article 38 of the ICJ. ${ }^{72}$ The failure to comply with those obligations may lead to state responsibility. ${ }^{73}$ The interaction between international and domestic law is governed by each state's constitution. ${ }^{74}$ Many constitutions regulate the international obligations of the state in the domestic sphere ${ }^{75}$ by two main doctrines, namely monism and dualism. ${ }^{76}$

Section 178 of the Constitution of the Kingdom of Thailand 2017 (B.E. 2560) ${ }^{77}$

70 Vienna Convention on the Law of Treaties art. 27. See Villiger, supra note 52, at 369-76; K. Schmalenbach, Article 27, in Dörr \& Schmalenbach, supra note 52, at 965-1012. See also Treatment of Polish Nationals and Other Persons of Polish Origin or Speech in Danzig Territory, Advisory Opinion, 1932 P.C.I.J. (ser. A/B) No. 44 (Feb. 4).

71 A. Aust, Modern Treaty Law and Practice 180 (2d ed. 2007).

72 D. Kennedy, The Sources of International Law, 2 Am. U. InT'L L. Rev. 1 (1987).

73 Draft Articles on Responsibility of States for Internationally Wrongful Acts 2001, arts. 1-2. For details, see B. Stern, The Elements of An Internationally Wrongful Act, in The Law of InTERnational ResponsibiLity 193-220 (J. Crawford et al. eds., 2010).

74 E. Stein, International Law in Internal Law: Toward Internationalization of Central-Eastern European Constitutions?, 88 Aм. J. InT’L L. 427 (1994); J. Goldsmith \& D. Levinson, Law for States: International Law, Constitutional Law, Public Law, 122 Harv. L. Rev. 1791 (2009). Cf. Hersch Lauterpacht argued that the relationship between international law and national law should be governed by international law. See A. Maniruzzaman, State Contracts in Contemporary International Law: Monist versus Dualist Controversies, 12 EuR. J. InT'L L. 309 (2001). Antonio Cassese argued that a matter of national legal tradition. See A. CASSESE, International Law in a Divided World 21-2 (1992).

75 A. Cassese, Modern Constitutions and International Law (1985); E. Stein, International Law in Internal Law: Toward Internationalization of Central-Eastern European Constitutions?, 88 Aм. J. InT'L L. 427 (1994); M. Kirby, International Law-The Impact on National Constitutions, 21 Am. U. InT’L L. Rev. 327 (2006).

76 E. Denza, The Relationship between International and National Law, in InTERNATIONAL Law 412-40 (M. Evans ed., 4th ed., 2006). For historical development, see L. Ferrari-Bravo, International and Municipal Law: The complementarity of legal systems, in The Structure and Process of International Law 715-44 (R. Macdonald \& D. Johnston eds., 1983).

77 Section 178 of the Constitution of the Kingdom of Thailand 2017 provides:

The King has the Royal Prerogative to conclude a peace treaty, armistice, and other treaties with other countries or international organisations.

Any treaty which provides for a change in Thai territories or external territories over which Thailand has sovereign 
only addresses the procedures of concluding an international treaty and the process of its transformation into the domestic law regime. ${ }^{78}$ Nevertheless, no more details are laid down on how customary international law or the general international legal obligations may be implemented in the Thai legal system. There are, however, a few Thai court decisions that address international obligations. In these cases, Thailand has obeyed international customary law in their decisions because they have already been incorporated into municipal law. ${ }^{79}$ In practice, Thailand often applies customary international law by adopting the doctrine of automatic incorporation ${ }^{80}$

\section{B. State Immunity}

As explained above, Thailand has not directly accepted the obligations under international customary law, but often implements those obligations as part of its national law under general principles of law. In accordance with the judgment in this case, the state immunity was accepted in Thailand as a part of international customary law; it has been thus incorporated into Thai national legal system. This is difference from many other countries who legislated the state immunity principle, including its exceptions, as their domestic law, offering foreign states immunity from legal proceedings. ${ }^{81}$

right or jurisdiction under a treaty or international law, or which requires the enactment of an Act for implementation, and other treaties which may have wide scale effects on the security of economy, society, or trade or investment of the country must be approved by the National Assembly. In this regard, the National Assembly shall complete its consideration within sixty days as from the date of receipt of such matter. If the National Assembly does not complete the consideration within such period of time, it shall be deemed that the National Assembly has given approval.

Other treaties which may have wide scale effects on the security of economy, society, or trade or investment of the country under paragraph two are treaties pertaining to free trade, common customs union, or the authorization of natural resources utilisation, or which cause the country to lose rights over natural resources, in whole or in part, or on any other treaties provided by law.

There shall also be a law prescribing procedures for the public to participate in the expression of opinions and to obtain necessary remedy from the effects of conclusion of a treaty under paragraph three.

Where a question arises as to whether any treaty constitutes a case under paragraph two or paragraph three, the Council of Ministers may request the Constitutional Court to render a decision thereon. The Constitutional Court shall complete its decision within thirty days as from the date of receipt of such request.

78 P. Limsira, The Treaty-Making Power of the 2017 Constitution of the Kingdom of Thailand, 10 J. E. AsIA \& INT'L L. 576 (2017).

79 Those following cases reflected the practices of international customary law in Thailand by adopting the obligations of erga omnes. See, e.g., Judgment of the Central Administrative Court No. Red 607-608/2549 (the dispute on the right to secret vote Procedure under art. 21(3) of the Universal Declaration of Human Rights); Judgment of the Civil Court Case No. Red 12083/2526 (the dispute on an immunity from an enforcement of diplomatic property under diplomatic immunity and privileges); Judgment of the Supreme Court Case No. 1142/2494 (the dispute on the right of hot pursuit)

80 D. Björgvinsson, The Intersection of International Law and Domestic Law 57 (2015).

81 E.g. Foreign Sovereign Immunities Act 1976 (US), State Immunity Act 1978 (United Kingdom), Singaporean State Immunity Act 1979 (Singapore), The South African Foreign States Immunities Act 87 of 1981 (South Africa), Pakistani 
Considering the emergence of the UNCSI in recent, Thailand should enact her domestic law for implementation after accession to the Convention. However, it is important to consider the place of jus cogens in the normative hierarchy, with its limitations on sovereign immunity. Thailand may have to consider jus cogens in the implementation of her new legislation.

\section{Conclusion}

The world has been confronting with an unprecedented pandemic situation for COVID-19. How we overcome the disease will be a reflection and a record of our humanity, as well as a lesson to the next generation. Fighting against COVID-19 represents unprecedented challenges. It requires new initiatives including transnational efforts. Instead of continuing the misinformation ${ }^{82}$ and the pandemic's blame game, all mankind should collaborate with each other, laying the groundwork to strengthen public health systems and better addressing future pandemics.

Moving forward, today's action will be recorded in history and transmitted to the next generation. Now, we can learn much how to deal with COVID-19 from the experiences of public and private sectors globally and domestically. How can we overcome this pandemic together as a whole, rather than just securing each national interest? How can mankind survive from the unexperienced crisis? The answers to these questions will be absolutely in our hands. Even though the current immune system is not easily tackling COVID-19, we should not let it defeat our humanity.

Received: September 1, 2020

Modified: October 15, 2020

Accepted: November 15, 2020

State Immunity Ordinance VI of 1981 (Pakistan), Malaysian Immunities and Privileges Act of 1984 (Malaysia), Malawi's Immunities and Privileges Act No. 16 of 1981 (Malawi), State Immunity Act 1985 (Canada), Foreign State Immunity Act of 1985 of the Commonwealth of Australia, Law No. 196/1985 (Australia), Argentina Law No 24/488 (Statute on the Immunity of Foreign States before Argentine Tribunals) 1995, Israeli Foreign State Immunity Law 2008 (Israel), and Act on the Civil Jurisdiction of Japan with respect to a Foreign State Act No. 24 of 2009 (Japan). For details, see M. Hemmi THE Jurisdictional Immunity of States in National Civil Proceedings for Allegations of Torture 40-9 (2009).

82 S. Evanega et al., Coronavirus Misinformation: Quantifying sources and themes in the COVID-19 'infodemic' (Oct. 1, 2020), https://allianceforscience.cornell.edu/wp-content/uploads/2020/09/Evanega-et-al-CoronavirusmisinformationFINAL.pdf. See also P. Ball \& A. Maxmen, The Epic Battle against Coronavirus Misinformation and Conspiracy Theories, 581 NATURe 371 (2020). 
